\title{
Physiological and genetic characterization of the Gly40Ser mutation in the glucagon receptor gene in the Sardinian population
}

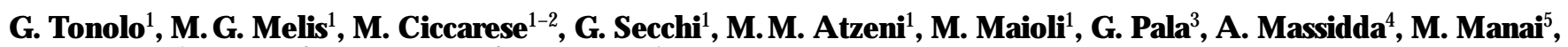 \\ R.M. P ilosu' ${ }^{5}, L$.-S. Li $i^{2}, H$. L uthman², M. Maioli ${ }^{1}$ on behalf of the Sardinian D iabetes $G$ enetic Study $G$ roup*
}

${ }^{1}$ C attedra di M alattie del M etabolismo, Instituto di Clinica M edica, U niversity of Sassari, Sassari, I taly

${ }^{2} \mathrm{R}$ olf $\mathrm{L}$ uft Center for D iabetes R esearch, K arolinska Institute, Stockholm, Sweden

${ }^{3}$ Servizio di D iabetologia, O spedale Civile, Nuoro, I taly

${ }^{4} \mathrm{D}$ iabetologia O spedale Civile, L anusei, I taly

${ }^{5}$ D iabetologia A SL 21, Cagliari, I taly

Summary A Gly40Ser amino acid substitution in the glucagon receptor gene has been associated with non-insulin-dependent diabetes mellitus (NIDDM), but the questions raised about its physiological implications have not been resolved. The aim of this study was to determine the frequency of the G ly40Ser mutation in different regions of Sardinia and to investigate the physiological implications of the mutation in glucose and insulin homeostasis. We studied a population of 691 subjects, selected on the basis of their Sardinian origin. O nly heterozygous subjects were found, 21 of $574(3.6 \%)$ in N ID D M patients and 5 of 117 in non-diabetic subjects ( $4.2 \%$ ). In northern Sardinia $3.4 \%$ of the NIDDM patients were carriers of the Gly40Ser substitution, $1.4 \%$ in central Sardinia, while $7.6 \%$ carried the substitution in the Southern part. No significant differences were found between hypertensive and normotensive subjects with respect to the presence of G ly40Ser. Ten subjects with G Iy40Ser were carefully matched for diabetic state, BMI, age, sex, and geographical origin with 10 patients with G ly40, and a glucagon infusion test was performed using 1 , 3,9 and $27 \mathrm{ng}$ glucagon $\mathrm{kg}^{-1} \cdot \mathrm{min}^{-1}$ for $30 \mathrm{~min}$. Blood for determination of glucose, glucagon, and insulin concentrations was drawn at 15-min intervals from the Controlateral arm. Plasma glucagon increased dose-dependently during the infusion with no significant difference between the two groups. Carriers of G ly40Ser had a significantly lower $(p<0.02)$ increase in plasma glucose concentration in response to glucagon infusion compared to $\mathrm{G}$ ly 40 homozygous subjects at all times, while the plasma insulin increase was not significantly different at any time. In conclusion, our results indicate that the $\mathrm{G}$ ly40Ser variation is not associated with NIDDM in the Sardinian population, and that its frequency varies in different parts of Sardinia. M oreover in vivo G ly40Ser plays a physiological role in the glucose homeostasis under glucagon control both in NIDDM and non-diabetic subjects. This latter result suggests that this amino acid substitution in the glucagon receptor may lead to a decreased blood glucose concentration because of the reduced stimulation of liver glucose output via the glucagon receptor. [D iabetologia (1997) 40: 89-94]

Keywords NIDDM, genetics, hypertension.
Non-insulin-dependent diabetes mellitus (NID D M) is a multifactorial disorder, displaying heterogeneity

R eceived: 18 July 1996 and in revised form: 150 ctober 1996

Corresponding author: D r. G. Tonolo, Servizio di D iabetologia, Cattedra di Malattie del M etabolismo, Istituto di Clinica M edica, V iale S.Pietro 8, I-07 100 Sassari, I taly

A bbreviations: NID D M, Non-insulin-dependent diabetes mellitus.

* see A cknowledgements both at the genotype and phenotype levels. It affects $3-8 \%$ of the Caucasian population over 45 years [ 1 , 2]. The genetic susceptibility to NIDDM is likely to involve separate but interrelated functions (for example insulin secretion, insulin resistance, obesity, abdominal fat patterning, intermediary metabolism, etc.) which have clinical consequences as a result of environmental influence. The increased understanding of the physiology and molecular biology of NIDDM has led to the identification of a number of genes. A mong different candidate genes investigated so far, a possible association between NIDDM and a 
Gly40Ser amino acid substitution in the glucagon receptor has been reported in the French and British populations [3, 4]. No heterozygous carriers of this substitution were found in Japanese, Finnish, or a small sample of German NIDDM patients [5-8]. However, in Finland, non-diabetic control subjects had a carrier frequency of $1.3 \%$ (4/306). These data suggest that the Gly40Ser substitution is not widely associated with NIDDM and that there might be problems of population stratification when cases and control subjects are compared.

Moreover, the questions raised about the in vivo pathophysiological implications of this mutation have not been resolved. G lucagon may be an element in the pathogenesis of diabetes, and glucagon antagonists may be potentially useful in its treatment by alleviation of the characteristically high gluconeogenesis in NID D M. Thus, the G ly40Ser amino acid variation in the glucagon receptor, generating a receptor less responsive to endogenous glucagon as clearly shown by in vitro studies [3,9], could be protective against hyperglycaemia. $\mathrm{O}$ the other hand, glucagon may also stimulate insulin secretion since biologically active glucagon receptors have been found in the pancreatic beta-cells [10]. In any case, no reports so far have described the in vivo biological function of the $\mathrm{G}$ ly40Ser variation in exon 2 of the glucagon receptor gene in relation to glucagon-stimulated hyperglycaemia.

We have determined the frequency and geographical distribution of the G ly40Ser variation in the exon 2 of the glucagon receptor gene on chromosome 17 in a large number of NIDDM patients from families with multiple cases of diabetes and non-diabetic subjects of Sardinian origin, and investigated the physiological consequences of this amino acid variation in vivo.

\section{Subjects and methods}

Subjects. The subjects were recruited from our ongoing studies of genetic and environmental effects on diabetes in multiplex NIDDM families from all parts of Sardinia. This study was conducted as a collaboration between several Sardinian A ntidiabetic $U$ nits (The D iabetes $G$ enetic Study $G$ roup of Sardinia). A total of 691 subjects, 574 with NIDD M and 117 non-diabetic subjects were investigated for the G ly40Ser amino acid variation of the glucagon receptor. Of the subjects 468 were NID D M siblings from a total of 189 families, while the remaining 223 (106 N ID D M and 117 non-diabetic subjects) were unrelated without documented family history for NIDDM. NID D M was diagnosed according to the following criteria: basal plasma glucose concentration more than $7.8 \mathrm{mmol} / \mathrm{l}$ on two different occasions or glucose higher than $11.1 \mathrm{mmol} / \mathrm{l}$ at 120 min after a 75-g oral glucose tolerance test (OGTT). The age at diagnosis was between 29 and 61 years and insulin was not required during the first 3 years after diagnosis. Normal subjects, over 55 years of age, were selected on the basis of a plasma glucose concentration less than $7.6 \mathrm{mmol} / \mathrm{l}$ at $120 \mathrm{~min}$ after an O G TT. A II subjects had at least parents and grandparents born in Sardinia. Of the 574 patients with NIDDM, 148 $(25.8 \%)$ originate from the A rchaic area of Sardinia in the middle of the island, so defined due to the pre-N eolithic settlement of the population that has remained genetically conserved [11]. $H$ ypertension was defined as either blood pressure higher than 140/90 mmH g on at least 3 different occasions over a period of three months without any antihypertensive treatment, or treatment with antihypertensive drugs.

The study was approved by the local ethics committee and all subjects gave informed oral consent to participation in the study.

D etection of the glucagon receptor mutation. G enomic D NA was isolated from leukocytes, and the G GT to A G T transition in exon 2 of the glucagon receptor gene, changing codon 40 from glycine to serine, was analysed after PCR amplification followed by restriction enzyme cleavage, using a previously described method [3] with modifications. PCR amplifications were performed with primers GCGR22, 5'TCTGTGGCTCA G TTA CCTCGTTA $3^{\prime}$ and GCGR23, 5'TCTGTCTGGTTGCTTGTGCA , 3' after initial denaturation for $3 \mathrm{~min}$. at $94^{\circ} \mathrm{C}, 35$ cycles consisting of $1 \mathrm{~min}$ at $94^{\circ} \mathrm{C}, 30 \mathrm{~s}$ at $55^{\circ} \mathrm{C}$ and $1 \mathrm{~min}$ at $72^{\circ} \mathrm{C}$ were performed, followed by a final extension of 5 min at $72^{\circ} \mathrm{C}$ using a Perkin E Imer D N A thermal cycler 4800 (Norwalk, CT, USA). E ach $10 \mu$ l reaction contained $150 \mathrm{ng} \mathrm{DNA}, 10 \mathrm{mmol} / \mathrm{l}$ Tris- $\mathrm{HCl}, \mathrm{pH} 8.8$ at $25^{\circ} \mathrm{C}$, $50 \mathrm{mmol} / \mathrm{K} \mathrm{KCl}, 1.5 \mathrm{mmol} / \mathrm{l} \mathrm{M} \mathrm{gCl}, 0.1 \%$ Triton $X-100,0.2$ $\mathrm{mmol} / \mathrm{l} \mathrm{dNTP}, 0.5 \mu \mathrm{mol} / \mathrm{l}$ of each primer, and $0.2 \mathrm{U}$ of $D$ yna Zyme (Finnzymes $0 \mathrm{y}$, Finland). A fter amplification, $10 \mu \mathrm{l}$ of the PCR product was cleaved with $5 \mathrm{U} \mathrm{B}$ stE II at $60^{\circ} \mathrm{C}$ for $2 \mathrm{~h}$, and the cleaved samples were separated by electrophoresis on a $3 \%$ agarose gel in Tris-Borate-E dta (TBE ) buffer containing ethidium bromide $(0.5 \mu \mathrm{g} / \mathrm{ml})$ and visualized by ultraviolet Light. A II B stE II resistant samples were re-analysed to verify the G ly40Ser coding change.

Glucagon infusion test. From our population we selected 20 normotensive subjects, 10 heterozygous G ly40Ser and 10 homozygous Gly40, for a glucagon infusion test. In each group six subjects were diabetic, while the other four were non-diabetic as defined by OG TT. The two groups were carefully matched for age, diabetes status and age at onset, body mass index. The NIDDM subjects were maintained in good metabolic control with oral antidiabetic agents $\left(\mathrm{HbA}_{1 \mathrm{c}}<7 \%\right)$ and were not on any other drug treatment. O ral antidiabetic agents were discontinued 3 days prior to the study. A II subjects were on a isocaloric diet with $50 \%$ carbohydrate and body weights were steady for at least 3 months before the study. A II experiments began between 07.00 and 08.00 hours after a 12-h fast. Indwelling catheters were placed into the antecubital veins in both arms for glucagon (Novo Nordisk Farmaceutici S.p.A., R oma, Italy) infusion and blood withdrawal. A fter a 30-min run-in period during which haemagel was infused at $3 \mathrm{ml} / \mathrm{h}$, glucagon (dissolved in haemagel) was infused at doses progressively increasing from 13,9 to $27 \mathrm{ng} \mathrm{kg}^{-1} \cdot \mathrm{min}^{-1}$, each concentration was infused for $30 \mathrm{~min}$ (study period). A the end of the glucagon infusions, haemagel was infused at $3 \mathrm{ml} / \mathrm{h}$ for an additional $60 \mathrm{~min}$ (recovery period). B lood was collected every 15 min in refrigerated $\left(4^{\circ} \mathrm{C}\right)$ tubes, containing EDTA for glucose and insulin determinations. Plasma glucose was immediately assayed (Beckman Inc.) and the remaining plasma was stored at $-35^{\circ} \mathrm{C}$ until insulin was assayed. Blood for glucagon determinations were collected in refrigerated glass tubes containing 500 kallekrein inhibitor units trasylol and $1 \mathrm{mg}$ E DTA for each $\mathrm{ml}$ whole blood and immediately centrifuged at 3000 $\mathrm{rev} / \mathrm{min}$ for $15 \mathrm{~min}$ at $4^{\circ} \mathrm{C}$, and the plasma was collected and 
Table 1. Clinical and biochemical characteristics of the NID D M patients and the non-diabetic subjects according to the presence of the G ly40Ser amino acid substitution

\begin{tabular}{|c|c|c|c|c|}
\hline & \multicolumn{2}{|l|}{ NIDDM } & \multicolumn{2}{|c|}{ Non-diabetic subjects } \\
\hline & G ly40 & Gly40Ser & G ly40 & Gly40Ser \\
\hline $\mathrm{n}$ & 503 & 21 & 112 & 5 \\
\hline A ge (years) & $60.6 \pm 9.6$ & $62.4 \pm 8.8$ & $60.8 \pm 5.4$ & $59 \pm 6$ \\
\hline Sex (female/male) & $245 / 258$ & $10 / 11$ & $67 / 45$ & $3 / 2$ \\
\hline Body mass index & $29.2 \pm 4.5$ & $29.1 \pm 4.7$ & $28.3 \pm 4.9$ & $24.6 \pm 6.3$ \\
\hline H ypertension (yes/no) & $256 / 247$ & $10 / 11$ & $51 / 61$ & $3 / 2$ \\
\hline D iabetes onset (years) & $49.5 \pm 9.6$ & $48.6 \pm 8.7$ & - & - \\
\hline $\mathrm{HbA}_{1 \mathrm{c}}(\%)$ & $7.6 \pm 2.1$ & $8.1 \pm 2.5$ & - & - \\
\hline Treatment $(\mathrm{D} / \mathrm{T} / \mathrm{I} / \mathrm{I})$ & $137 / 264 / 46 / 56$ & $7 / 8 / 6 / 0$ & - & - \\
\hline Total cholesterol (mmol/l) & $5.66 \pm 1.06$ & $5.74 \pm 0.85$ & $5.82 \pm 1.21$ & $6.05 \pm 1.00$ \\
\hline HDL-cholesterol (mmol/l) & $1.34 \pm 0.40$ & $1.24 \pm 0.31$ & $1.34 \pm 0.36$ & $1.55 \pm 0.38$ \\
\hline LD L-cholesterol (mmol/l) & $3.67 \pm 1.03$ & $3.67 \pm 0.64$ & $3.67 \pm 1.00$ & $3.90 \pm 0.67$ \\
\hline Triglycerides (mmol/l) & $1.55 \pm 1.04$ & $1.39 \pm 0.62$ & $1.42 \pm 0.74$ & $1.22 \pm 0.14$ \\
\hline
\end{tabular}

$\mathrm{D}$ ata are given only for subjects in whom all data were available, data are expressed as mean \pm SD, the only significant difference was detected for H D L-cholesterol between heterozy-

gous subjects with the Gly40Ser variation, NIDDM and nondiabetic subjects $(p<0.05)$

stored in glass tubes. A II the samples from each patient were run in the same assay. Blood pressure was measured three times at the end of each glucagon infusion step with a mercury sphygmomanometer, at the same time radial pulse rate was determined. Plasma glucagon was measured by radioimmunoassay, using a double antibody kit (D iagnostic Products Corporation, Los A ngeles, Calif., U SA ; intra- and inter-assay coefficients of variation were less than $6 \%$ ), plasma insulin was measured by radioimmunoassay (INCSTAR, Stillwater, M inn., USA, intra- and inter-assays coefficients of variation were less than $9 \%$ ).

\section{Statistical analysis}

Values are mean $\pm S D$ except for the glucagon infusion test where SE M was used. D ifferences between groups were tested using the paired or unpaired Student's t-test and A NOVA with repeated measurements design was used to analyse the results of the glucagon infusion test. Differences in frequency were tested with the chi-square analysis. The statistical calculations were performed using the SIG M A STA T statistical package.

\section{Results}

G lucagon receptor gene screening. Of our population of 691 subjects, a total of 26 ( 13 males and 13 females) were heterozygous carriers of the G ly40Ser amino acid substition. No homozygous Ser40 subjects were found. In particular 21 of 574 NID D M patients and 5 of 117 non-diabetic subjects were heterozygous carriers of the G ly40Ser amino acid variation. Thus, the prevalence of this mutation was 3.6\% in NIDDM patients and $4.2 \%$ in non-diabetic subjects (non significant, $\chi^{2}=0.003, p=0.96$ ). In detail, among the 514 NIDDM patients from whom ancestral data were available: in north Sardinia 9 of 261 (3.4\%) were heterozygous carriers of the G ly40Ser, while in the center 2 of $148(1.4 \%)$ were heterozygous, and in the south 8 of $105(7.6 \%)$. The prevalence was significantly different between south and central $\left(\chi^{2}=4.81, p=0.028\right)$ and between south and the combined central and north regions $\left(\chi^{2}=4.4, p=0.036\right)$, while there was no statistical significance between the north and the central regions $\left(\chi^{2}=0.89, p=0.346\right)$ and between the south and the north regions $\left(\chi^{2}=0.89, p=0.346\right)$. No significant differences for sex or for the presence of hypertension were present in relation to the glucagon amino acid variation. None of the variables measured in NIDDM patients were significantly different in the heterozygous carriers as compared to the patients homozygous for G ly40. A slight difference was observed for plasma HDL-cholesterol between diabetic and non-diabetic carriers (Table 1). A II the measured variables were not significantly different as shown Table 1.

G lucagon infusion test. The recovery of glucagon dissolved in haemagel was $91 \pm 3 \%$ (mean $\pm S D$ ). Plasma glucose changes during the test are expressed as incremental variations calculated after subtraction of the basal value (time 0). Plasma glucose increased in a dose-dependent manner in both carriers of Gly40Ser and non-carriers during glucagon infusion. The glucose incremental values were significantly higher at all time points during the glucagon infusion test in the $\mathrm{G} \mathrm{ly} 40$ subjects as compared to the G ly40Ser heterozygotes ( $p=0.02$, Fig. 1 ). A dose as small as 1 $\mathrm{ng} \cdot \mathrm{kg}^{-1} \cdot \mathrm{min}^{-1}$, which increased the basal glucagon concentration only by $50 \%$ significantly increased 


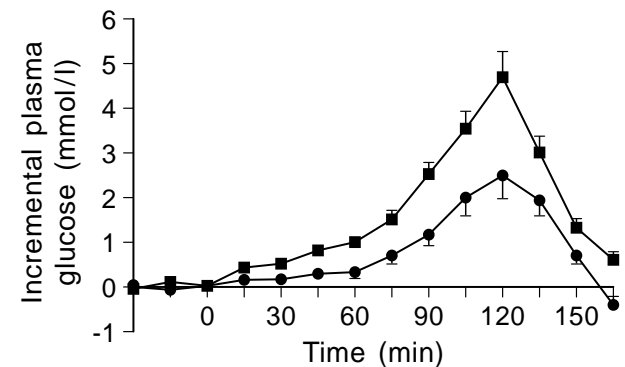

Fig. 1. The incremental plasma glucose concentrations above basal glucose are shown for heterozygous Gly40Ser (O) and G ly40 homozygous $(\square)$ mean \pm SE M. Glucagon was infused at stepwise increased concentrations $1 \mathrm{ng} \cdot \mathrm{kg}^{-1} \cdot \mathrm{min}^{-1}(30-$ $120 \mathrm{~min}), 3 \mathrm{ng} \cdot \mathrm{kg}^{-1} \cdot \mathrm{min}^{-1}(30-60 \mathrm{~min}), 9 \mathrm{ng} \cdot \mathrm{kg}^{-1} \cdot \mathrm{min}^{-1}(60$ $90 \mathrm{~min})$ and $27 \mathrm{ng} \cdot \mathrm{kg}^{-1} \cdot \mathrm{min}^{-1}(90-120 \mathrm{~min})$

Table 2. Plasma glucagon and insulin levels before ( -15 and $0 \mathrm{~min}$ ) during (30-120 $\mathrm{min}$ ) and after (135-180 min) glucagon infusion at the different doses in the two groups of patients, heterozygous carriers of the G ly40Ser variation and homozygous G ly40

\begin{tabular}{rccccc}
\hline $\begin{array}{r}\text { Time } \\
\text { (min) }\end{array}$ & \multicolumn{2}{c}{ G lucagon (pmol/l) } & & \multicolumn{2}{c}{ Insulin (pmol/l) } \\
\cline { 2 - 3 } \cline { 5 - 6 } & Gly40 & Gly40Ser & & Gly40 & Gly40Ser \\
\hline-15 & $40 \pm 1.7$ & $43 \pm 1$ & & $56 \pm 12$ & $44 \pm 7$ \\
0 & $40 \pm 2.3$ & $42 \pm 1$ & & $62 \pm 12$ & $38 \pm 5$ \\
30 & $65 \pm 2.3$ & $59 \pm 4$ & & $67 \pm 6$ & $52 \pm 5$ \\
60 & $78 \pm 17$ & $77 \pm 12$ & & $72 \pm 11$ & $55 \pm 5$ \\
90 & $118 \pm 20$ & $142 \pm 18$ & & $114 \pm 21$ & $109 \pm 22$ \\
120 & $258 \pm 27$ & $303 \pm 26$ & & $194 \pm 59$ & $158 \pm 42$ \\
135 & $109 \pm 33$ & $89 \pm 18$ & & $142 \pm 23$ & $105 \pm 20$ \\
150 & $47 \pm 8$ & $54 \pm 7$ & & $85 \pm 12$ & $62 \pm 14$ \\
180 & $47 \pm 8$ & $42 \pm 1$ & & $43 \pm 9$ & $31 \pm 12$ \\
\hline
\end{tabular}

D ata are mean \pm SE M . N o significant differences were evident between groups at any time for both plasma glucagon and insulin. A significant increase within groups was evident for both plasma glucagon and insulin levels $(p<0.001)$ during exogenous glucagon infusion

the plasma glucose in both groups. However, these physiological glucagon levels increased the glucose concentration significantly more in $\mathrm{G} \mathrm{Iy} 40$ subjects as compared to the heterozygous carriers $(p=0.014)$. The area under the curve $(A \cup C)$ of the incremental plasma glucose levels during the glucagon infusion (from $0 \mathrm{~min}$ to $120 \mathrm{~min}$ ) was significantly larger $(p=0.011)$ in Gly40 homozygotes $184 \pm 33$ (mmol/ l) - min vs Gly40Ser heterozygotes $96 \pm 23$ (mmol/ I) - min. Plasma insulin and glucagon were not significantly different in the two groups before glucagon infusion. D uring the glucagon infusion, both insulin and glucagon increased in a dose-dependent manner to similar levels (Table 2). A fter the end of glucagon infusion, plasma glucose, insulin, and glucagon decreased in the two groups, returning to basal values after $60 \mathrm{~min}$. Systolic and diastolic blood pressure and heart rate were stable during the test with no differences between the groups (data not shown).

\section{Discussion}

The results of our study demonstrate that the G Iy40Ser variation in the glucagon receptor gene is not associated with NIDDM in the Sardinian population, suggesting that this amino acid substitution alone is not a significant factor in the development of familiar NIDDM in this population. Previously $\mathrm{H}$ ager et al. [3] showed a non-significant difference in the prevalence of the G ly40Ser mutation in a small samples of Sardinian NIDDM patients $(8.3 \%)$ when compared with non-diabetic subjects $(3.1 \%)$, although significant association was found in the French population. $\mathrm{O}$ ur data do not differ from those obtained by $\mathrm{H}$ ager et al. with respect to the Sardinian population, and when the two data sets from Sardinia are combined the difference between NIDDM and control subjects is still not significant (4.3\% in NIDDM and $3.8 \%$ in control subjects). I ndeed, in our subgroup of NID D M patients who originated from the south of Sardinia, we found a prevalence of heterozygotes for the G ly40Ser substitution of about $8 \%$. A $n$ interesting result from our study is the major difference in distribution of the G ly40Ser variation across the different Sardinian regions. In fact, in the south the frequency of G ly40Ser was significantly higher than in the central region (the most archaic and genetically homogeneous area), and almost twice as high, although not significantly, than in the north. Genetically, Sardinians are very different from most European populations since the colonization dates back to pre-N eolithic times, and cultural, linguistic and geographical factors have promoted isolation of the Sardinians $[11,12]$. The Gly40Ser amino acid substitution has been observed at different prevalences in different populations [3-6], and also within the same population $[7,8]$. These data fit well with our findings in the different regions of Sardinia.

G lucagon is a 29 amino acid peptide hormone that is secreted from the pancreatic alpha-cells in response to hypoglycaemia. It is a key regulator of hepatic glucose production through hepatic gluconeogenesis and glycogenolysis [13]. G lucagon receptors have been identified in a restricted number of tissues besides liver including heart, adipose tissue, pancreatic beta-cells - where glucagon may potentiate glucose-induced insulin secretion from beta cells during fasting - kidney, and brain, but the role of glucagon in these tissues is not fully understood [14-17]. In cultured rat hepatocytes, glucagon receptor mR N A levels are up-regulated in the presence of high glucose concentrations in the culture medium, and glucagon is able to down-regulate the expression of its own receptor [18]. Increased endogenous glucose production through gluconeogenesis and glycogenolysis contribute to the pathogenesis of hyperglycaemia in NIDDM. A dditionally, it has been shown that the regulation of glucagon secretion is impaired in 
NIDDM and can contribute to the hyperglycaemic state [19]. Thus, glucagon might be an additional contributing factor in the pathogenesis of diabetes and glucagon receptor antagonists have been proposed as being potentially useful in the treatment of diabetes, by alleviating the characteristically high liver glucose output. From these data we can hypothesize that an amino acid variant in the glucagon receptor gene, which reduces the effects of glucagon would not play a major role in the development of NIDDM. The fact that the G ly40Ser amino acid substitution results in a reversion to the sequence of the rat glucagon receptor sequence, suggests a role of this region in the receptor activity, as has been described for the glucagon like peptide-1 receptor [20]. In any case, although in vitro binding studies suggest a reduced activity of the mutated receptor [3,9], the exact in vivo physiological role of the G ly40Ser amino acid substitution in the glucagon receptor gene has not been addressed until now. The present study was therefore designed to determine the in vivo role of the variant in terms of glucose production under glucagon control. To explore the biological effects of the G ly40Ser variant we evaluated the response of plasma glucose and insulin to a stepwise increase in the glucagon concentration. E ven though insulin plasma concentration increased during glucagon infusion, the infusion of only 1 and $3 \mathrm{ng} \cdot \mathrm{kg}^{-1} \cdot \mathrm{min}^{-1}$, which raised the endogenous glucagon plasma levels within the physiological range, only 20 and $35 \mathrm{pmol} / \mathrm{l}$, respectively, resulted in a statistically significant rise in glucose in both groups. Subjects who were heterozygous carriers of the Gly40Ser variant of the glucagon receptor showed similar glucagon and insulin increases, but a significantly lower increase in plasma glucose, irrespective of diabetes status. This indicates that the G ly40Ser variant reduces the activity of the hepatic receptor in vivo. Thus, from our data, it appears that this variant of the glucagon receptor is responsible for a significant reduction of glucose production in response to physiological or slightly over-physiological increase in plasma glucagon, while insulin secretion appeared unaffected by the presence of the variant glucagon receptor. R ecently, it was shown that $\mathrm{BH}$ K cells transfected with the $\mathrm{G}$ ly40Ser glucagon receptor had a right shift in the dose-response curve for glucagon stimulated CA M P production at glucagon concentrations of 1-10 pmol/l [9], compatible with our concentrations during in vivo infusion.

It has long been known that partial glucagon suppression could be useful in the management of diabetic patients [21]. Since glucagon receptors are present on the beta cell and are supposed to stimulate insulin secretion [10,22], it may be that a reduction in the activity of this receptor may contribute to a failure of insulin secretion in NIDDM patients with inadequate insulin secretion. Indeed a right shift has been reported in the dose response curve of glucagon stimulated insulin secretion in $\mathrm{R} I \mathrm{~N}$ cells transfected with the mutant receptor, as compared to the same cell line transfected with the wild type receptor [9]. In that experiment the effects were seen at concentrations of glucagon $10^{3}$ to $10^{4}$ higher than those obtained during our in vivo experiment. O ur data indicate that in vivo insulin secretion is not different in heterozygous carriers of the G ly40Ser as compared to normal subjects during increase in plasma glucagon concentration in the physiological range. This observation suggests that the effects of glucagon on insulin secretion are minimal under these conditions.

In summary our data demonstrate that 1 ), in the Sardinian population the G ly40Ser variant in the glucagon receptor gene is not preferentially associated with NIDDM ; 2), there are significant differences in G ly40Ser carrier frequency in different parts of Sardinia; 3), heterozygous carriers of the G ly40Ser glucagon receptor variant display significantly decreased glucose levels during glucagon stimulation within the physiological range.

A cknowledgements. The members of The Sardinian D iabetes Genetic Study G roup (SD G SG ) are as follows:

Prof. M. Maioli, Dr. G. Tonolo (Sassari) and Dr. G. Pala (Nuoro) (coordinators); Dr. M. Ciccarese, D r. M.G. Melis, Dr. M.M. A tzeni, Ms. G. Secchi (Sassari); Dr. M. Manai, Dr.A.M. Sanna and D r.R.M. Pilosu (Cagliari); M s. N. Pintori (Nuoro); D r. A. M assidda and Dr.G. M eloni (L anusei); Prof. R. Cirillo and Dr. E. Cossu (Cagliari); D r. S. M ereu and Dr. A. Gigante (Sorgono); Dr. M. Mastinu, Dr. M. Cossu, D r.M.A. M ugheddu (O ristano); D r. A . Corda (Iglesias); D r. G. Filigheddu and Dr.A. Cusseddu (Tempio); D r. F. Sanciu (Olbia); D r. E. Secchi (Ozieri); D r. P. Solinas (A Ighero); D r. M. Pisano (I sili)

This work was supported in part by grants from R egione Sardegna and also (H.L., L.S.L.) from the Swedish M edical R esearch Council (09109), Swedish Diabetes A ssociation and the following foundations: ULF Widengren Petrus and Augusta Hedlund, G amla Tjanarinnor and Novo Nordisk.

D r. M. Ciccarese and D r. M.G. M elis have a grant "D ottorato di Ricerca in Fisiopatologia Medica" from the U niversity of Sassari and the EUC.

\section{References}

1. Hamman R F (1992) G enetic and environmental determinants of non-insulin-dependent diabetes mellitus (NIDD M ). D iabetes M etab R ev 8: 287-338

2. Garancini MP, Calori G, Ruotolo G et al. (1995) Prevalence of NIDDM and impaired glucose tolerance in I taly: an O G TT-based population study. 38 (3): 306-313

3. Hager J, H ansen L, Vaisse C et al. (1995) A missense mutation in the glucagon receptor gene is associated with noninsulin-dependent diabetes mellitus. Nature Genetics 9: 299-304

4. G ough SCL, Saker PJ, Pritchard LE et al. (1995) Mutation of the glucagon receptor gene and diabetes mellitus in the UK: association or founder effect? Hum Mol Genet 9: 1609- 1612 
5. Fujisawa T, Ikegami $H$, Yamato $E$ et al. (1995) A mutation in the glucagon receptor gene (G ly40Ser): heterogeneity in the association with diabetes mellitus. Diabetologia 38 : 983-985

6. H uang X, O rho M , L ehto M , G roop L (1995) L ack of association between the Gly40Ser polymorphism in the glucagon receptor gene and NIDDM in Finland. Diabetologia 38: $1246-1248$

7. Jaksch M, H ofman S, G erbitz K D (1996) G lucagon receptor gene mutation in NID D M. D iabetologia 39: 248

8. Poller W, B reizel R G, Bollen CC, Merklein F, Froguel P, Hager J (1996) A ssociation of a glucagon receptor mutation in $\mathrm{G}$ erman patients with familial NIDDM. Diabetes 45[Suppl 2]231A (A bstract)

9. $H$ ansen LH, A brahamsen N, H ager J, Jelinek L, K indsvogel W, Froguel P, Nishimura E (1996) The G ly40Ser mutation in the human glucagon receptor gene associated with NIDDM results in a receptor with reduced sensitivity to glucagon. Diabetes 45: 725-730

10. Van Schravendijk CFM, Foriers A, H ooghe-Peters E L, R ogiers V, De M eyts P, Sodoyez J C, Pipeleers G (1985) Pancreatic hormone receptor on islet cells. Endocrinology 117: 806-848

11. Cappello N, Rendine S, G riffo R, Mameli GE, Succa V, Vona G, Piazza A (1996) Genetic analysis of Sardinia: I. $D$ ata on 12 polymorphisms in 21 linguistic domains. A nn H um G enet 60: 125-141

12. Piazza A (1993) Who are the Europeans? Science 260: 1767-1769

13. Claus TH, Park CR, Pilkis SJ (1983) Glucagon and gluconeogenesis. In: L efebvre PJ (ed) G lucagon, vol 1. Springer, Berlin , pp 315-360
14. Paolisso G, Buonacore S, Gentile S et al. (1990) Pulsatile glucagon has greater hyperglycemic, lipolytic and ketogenic effects than continuous hormone delivery in man: effect of age. D iabetologia 33: 272-277

15. Pipeleers DG, Schuit FC, Van Schravendijk FH, Van De Winkel M (1985) Interplay of nutrients and hormones in the regulation of glucagon release. Endocrinology 117: 817-823

16. K awai K, Y okota C, Watanabe Y, Yamashita K (1995) E vidence that glucagon stimulates insulin secretion through its own receptor in rats. $D$ iabetologia 38: 274-276

17. Christophe J (1995) Glucagon receptors: from genetic structure and expression to effector coupling and biological responses. Biochim B iophys A cta 1241: 45-57

18. A brahamsen N, L undgren K, N ishimura E (1995) R egulation of glucagon receptor $\mathrm{mRNA}$ in cultured primary rat hepatocytes by glucose and CA MP. J Biol Chem 270: 15853- 15857

19. L efebvre P, Paolisso G, Scheen A (1991) The role of glucagon in non-insulin dependent (type 2) diabetes mellitus. In: Sakamoto N, A ngel A, H otta N (eds) New directions in research and clinical work for obesity and diabetes mellitus. E Isevier Science Publisher BV A msterdam, pp 25-29

20. Van Eyll B, Lankat R (1994) Cloning and functional expression of the $G L P-1$ receptor from a human insulinoma. Diabetes 43:[Suppl 1]179A (A bstract)

21 G erich J E , L orenzi M, Bier D M , Schenider V, Tsalikian E , K aram J H, Forsham PH (1975) Prevention of human diabetic ketoacidosis by somatostatin. E vidence for an essential role of glucagon. N E ngl J M ed 292: 985-989

22. B onds E , M arri G, M arri V (1985) Promotion of insulin secretion by glucagon. $L$ ancet 2: 415-416 